\title{
自然言語処理特集号 言語的オントロジーの構築・連携・利用
}

「オントロジーってシソーラスとは何が違うの? 」,「日本語語彙大系はシソーラスだよね？」， 「WordNetはオントロジーなのかな？」， etc. 言語処理の関係者からよく出される質問である. 結局のところ，オントロジーとは何かという定義がしっくりと理解されていないのではないだ ろうか. そもそもオントロジーの定義って何だろうか.「概念化の明確な規定」1などと言われ てもよく分からない...

計算機科学におけるオントロジーとは，「処理対象の世界に登場する事物・実体を概念として 抽出し，それらの間の本質的な関係を形式的に定めた体系」と言えるだろう。形式的ということ がここでは重要で，このために，推論などの論理的な処理が実現可能となる，すなわち，上位・ 下位関係 $(\mathrm{ISA})$ や全体・部分関係 $(\mathrm{PART}-\mathrm{OF})$ などの階層的な概念関係を利用して推論を行う.

本特集でいう「言語的オントロジー」とは，語彙に関する資源 (lexical resource)のうち，とく に語彙が指示する意味・概念間の関係が付与されたものとゆるく考える。この意味で, WordNet では何種類かの語彙概念関係が定義されており，言語的オントロジーの範疇にはいる，一方， 通常言われるシソーラスにも BT (broader term)/NT (narrower term) などの語彙の概念的な関 係が付与されているが，さほど形式的な観点には重点は置かれていないので，オントロジーと 呼ぶには抵抗がある。しかしながら，いずれにせよ，これらの境界線はあいまいであり，各種 の語彙資源は, 単純な辞書からいわゆる形式的な上位オントロジーまでの連続体の中に位置づ けられる。

近年，セマンティックWebの実現が待望されるなか，さまざまなリソースに対して，処理主 体が理解・操作可能な意味的マークアップを行うことが必要であり，このための基盤としてのオ ントロジーの重要性が叫ばれている。リソースはさまざまなメディアにより実現されるが，そ の主なものは言語メディアによるものである。このため, テキストから対象ドメインにおける オントロジー的知識を抽出することや，様々な言語や対象分野に特化した語彙資源をつなぐた めのバックボーンとしてのオントロジーを構築し, 実際に語彙資源やオントロジーを自在に連 携させること，さらには，「言語的オントロジー」を利用して，言語処理の精度や適用領域を拡 大することなどが求められている。海外においては，NLP 技術の主要な会議の他にも，言語資 源と評価に関する大規模な国際会議 (LREC: Language Resources and Evaluation) が開催されて おり，語彙資源やオントロジーに関連する多くの研究発表が行われている．また，このトピッ クに特化したワークショップ (OntoLex) も LREC やセマンティック Web 関係の会議に併設さ れる形で定期的に開催されている。

以上のような背景認識と状況のもと，2007 年度の言語処理学会年次大会 (NLP2007)におい

\footnotetext{
${ }^{1}$ http://www.ksl.stanford.edu/kst/what-is-an-ontology.html
} 
て，「言語的オントロジーの構築・連携・利用」というワークショップを企画した. 同ワーク ショップでは, 招待講演 1 件, 論文発表 11 件が行われ, 100 名以上の参加者があった. 11 件の 論文のトピックは，オントロジー獲得・学習に関するもの：4 件, NLP のためのオントロジー 構築，オントロジーを利用した NLP: 4 件, 多言語・多文化とオントロジーに関するもの：3 件, であり，ほほ期待した分布であった。

上記のワークショップの成功を受けて，本特集号の論文募集を行った. 当初に応募があった 論文は 8 件であり，そのなかから 4 件の論文を採録し本号に掲載した. 4 件の採録論文には，ユ ニークなトピックや挑戦的なテーマを扱った論文も含まれており，はからずも言語的オントロ ジーの範囲の広さを示す結果となった，願わくは，上記のワークショップで発表された内容を 発展させた論文投稿がもっと多ければ，ワークショップと本特集号のより密接なものにするこ とができたと考えている.

さて, 本論文の編集過程においては, 特集号であることを考慮し, なるべく迅速に採否を決 定する工夫を試みた。最大 2 回の査読で採否を決定することとし，そのかわり 2 名の査読者が 並行して査読を行った。 また, 論文ごとに 1 名のメタレビューアを割り当て, 必要に応じて両 査読結果の調整を行っていただいた。結果として, 当初予定していたスケジュールに大幅に遅 れることなく充実した査読が行えたと考える. 編集委員をお願いした皆様には, 平均して 2 本 の論文の查読と 1 本の論文のメタレビューをお願いした. 多忙な中をお引き受けいただいた編 集委員の皆様に感謝する次第である.

言語的オントロジーは辞書から形式的オントロジーに至る広いスペクトラムに分布する意味・ 概念を扱う語彙資源の総称である. 今後のセマンティック Web や意味コンピューティングを 下支えする重要な存在であることは疑いがない。この分野における研究がいっそう盛んになる ことを祈るとともに, 適切な時期に再びワークショップや論文特集が企画されることを期待し たい.

特集号 ゲストエディタ

林 良彦 (大阪大学) 